\title{
Progress Reports for Period January 1-31, 1995 Joint UK/US Radar Program
}
R. E. Twogood
J. M. Brase
H. F. Robey
D. D. Mantrom
C. Rino
D. H. Chambers
J. Belyea

This is an informal report intended primarily for internal or limited external dietribution. The opinions and conclusions stated are those of the author and may or may not be thoce of the Laboratory.

Work performed under the auspices of the U.S. Department of Energy by the Lawrence Livermore National Laboratory under Contract W-7405-ENG-48.
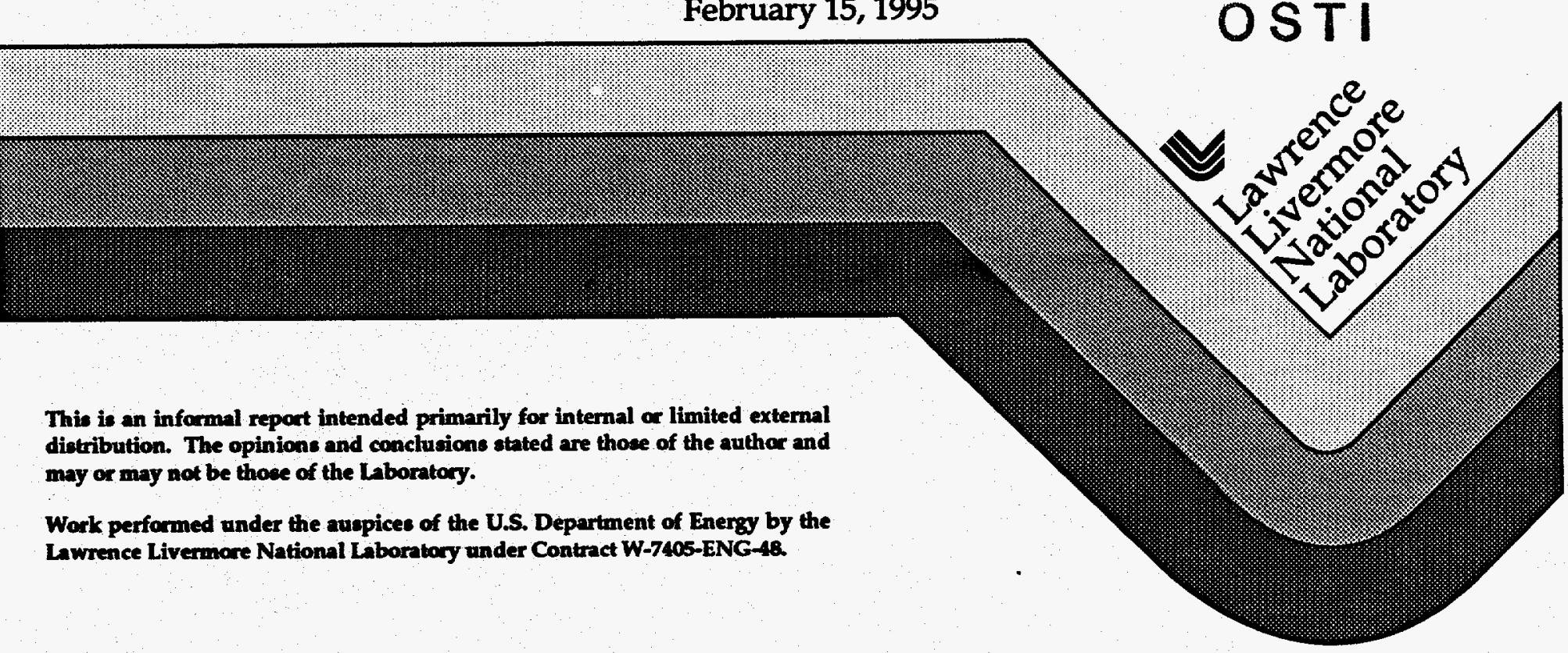


\section{DISCLAIMER}

This document was prepared as an acoount of work sponsored by an agency of the United States Government. Neither the United States Covernment nor the University of California nor any of their employees, makes any warranty, express or implied, or assumes any legal liability or responsibility for the accuracy, completeness, or usefulness of any information, apparatus, product, or process discioeed, or represents that its use would not infringe privately owned rights. Reference herein to any specific commercial product, process, or service by trade name, trademark, manufacturer, or otherwise, does not necessarily constitute or imply its endorsement, recommendation, or favoring by the United States Government or the University of California. The views and opinions of authors expressed herein do not necessarily state or reflect those of the United States Covernment or the University of California, and shall not be used for advertising or product endorsement purposes.

This report has been reproduced directly from the best available copy.

Available to DOE and DOE contractors from the Office of Scientific and Technical Information

P.O. Box 62, Oak Ridge, IN 37831

Prices available from (615) 576-8401, FTS 626-8401

Available to the public from the

National Technical Information Service

U.S. Department of Commerce

5285 Port Royal Rd.

Springfield, VA 2216 


\section{DISCLAIMER}

Portions of this document may be illegible in electronic image products. Images are produced from the best available original document. 
Progress Reports for period January 1-31, 1995

Joint UK/US Radar Program 2/15/95

Organization: LLNL

Program: P.LLN.1010 Airborne RAR/SAR

Principal Investigator: Richard E. Twogood

Current Objectives:

Modify Hughes $\mathbf{x}$-band radar for airborne implementation.

Upgrade to polarimetry, high-power, and add SLAR mode.

Deploy in UK/US field experiments as needed.

\section{Recent accomplishments:}

This airborne (Hughes' A-3) system for future SAR and eventually, SLAR imaging at low grazing angles remains on schedule and within planned budgets. Hughes and LLNL continued work on system integration, radar hardware, and associated control hardware and software. The belly radome design modification previously completed is now being procured.

The overall radar and testbed remains on schedule for engineering checkout in April 1995, pending the arrival of FY95 funds as expected.

Milestones for the reporting period:

No major milestones scheduled for January 95.

Expected milestones for the ensuing period:

April 1995 Engineering Checkout(s)

June 1995 First experimental deployment

\section{Other Issues:}

None

Planned expenditures versus actuals:

FY95 Budget Plan: \$1500K

January 95 costs: $\quad \$ 70.5 \mathrm{~K}$

Year-to-date costs: $\quad \$ 234.6 \mathrm{~K}$ 
Organization: LLNL

Program: P.LLN.1020 Radar Data Processor

Principal Investigator: James M. Brase

Current Objectives:

Integration and test of the real-time SAR processor for the Hughes airborne radar; define and develop the SAR Doppler and related analysis software for this unique system; develop the similar system for the UK testbed (OITB).

Recent accomplishments:

The SAR processors are running on all processors in real time.

Milestones for the reporting period:

Completed real time SAR processor testing using JPL data.

Expected milestones for the ensuing period:

Integration of disk array by February ' 95 .

Start high-speed tape drive integration February '95.

Full-speed operation demo by March ' 95 .

\section{Other Issues:}

None.

Planned expenditures versus actuals:

FY95 Budget Plan: $\quad \$ 750 \mathrm{~K}$

January 95 costs: $\quad \$ 45.0 \mathrm{~K}$

Year-to-date costs: $\quad \$ 293.5 \mathrm{~K}$ 
Organization: LLNL

Program: P.LLN.1030 Ground-based SAR Signal Processing Workstation

Principal Investigator: James M. Brase

Current Objectives:

Develop capabilities for motion compensation and autofocus for Hughes SAR and UK system. Enhance SAR processors with multi-look software. Analyze the low-grazing angle (LGA) processing steps and improve performance of LGA processing.

\section{Recent accomplishments:}

Work was begun on precision SAR processor. Reports on 2D approach and software requirements are in preparation. Work is continuing on nonlinear filters for LGA processing.

Milestones for the reporting period:

Expected milestones for the ensuing period:

Initial release of precision SAR processor (motion compensation and auto focus) in March '95.

Other Issues:

None.

Planned expenditures versus actuals:

FY95 Budget Plan: January 95 costs:

$\$ 750 \mathrm{~K}$

Year-to-date costs: 
Organization: LLNL

Program: P.LLN.1040 Static Airborne Radar

Principal Investigator: Richard E. Twogood

Current Objectives:

Procure GFE excess equipment including aerostats, platforms, and ancillary systems. Perform checkout of hardware. Assess options for stabilized realaperture radar experiments using these aerostats systems. FY95 funding permitting, include these systems in radar experiments beginning in summer 1995.

\section{Recent accomplishments:}

Systems check-out for aerostats, mooring platforms and support hardware has progressed and we are in a position to finalize system configurations for nearterm tests. The baseline system using the LLNL platform obtained from Beaumont, TX has been designed. Start-up of the groundstation integration, plus selection of tasks for the LLNL and/or AUTEC mooring platforms, will be made during February.

\section{Milestones for the reporting period:}

None.

Expected milestones for the ensuing period:

Determine issues and costs for IR support at October 95 Autec test.

Initial radar system checkout and experiments, June 1995.

\section{Other Issues:}

The UK has indicated providing an aerostat for Autec in October is a high priority. IR systems would be deployed (presumably the existing ERIM sensors already successfully used, but they would need to be fitted to the aerostat). The existing budget for this task will be insufficient for both objectives (radar support for COPE and IR support for Autec). At this point it appears slippage of the radar support is most likely unless additional funds for IR support are available through the IR tasks. Final decision on these issues is expected to be made at Feb. 95 meeting in UK.

Planned expenditures versus actuals:

FY95 Budget Plan: $\quad \$ 1000 \mathrm{~K}$

January 95 costs:

$\$ 19.2 \mathrm{~K}$

Year-to-date costs:

$\$ 136.2 \mathrm{~K}$ 
Organization: LLNL

Program: P.LLN.1050 Multi-Aperture Space-Time Array Radar

Principal Investigator: James M. Brase

Current Objectives:

Perform feasibility study and preliminary design of a multi-aperture radar for high resolution, in both range and azimuth, imaging of the ocean surface.

Recent accomplishments:

Not applicable - project starts upon FY95 funding approvals.

Milestones for the reporting period:

None.

Expected milestones for the ensuing period:

Initiation of project in February '95; preliminary discussion with Keith Ward in March '95.

Other Issues:

None.

Planned expenditures versus actuals:

FY95 Budget Plan: \$200K

January 95 costs: $\quad \$ 0 \mathrm{~K}$

Year-to-date costs: $\quad \$ 0 \mathrm{~K}$ 
Organization: LLNL

Program: P.LLN.1060 Radar Field Experiments

Principal Investigator: H. Robey, David Mantrom

Current Objectives:

Complete analysis of Loch Linnhe 1994 data.

Recent accomplishments:

GPS tracking data for the LL94 experiments has been obtained and is being incorporated into kinematic analysis of internal wave patterns observed by radars. The effect of cross track shear on the kinematics of the internal wave patterns is being completed as well.

Completed analysis of historical density profiles for the vicinity of the COPE trial in Sept. 1995.

Milestones for the reporting period:

A report on historical density profiles and dispersion relations for the vicinity of the COPE trial will be completed by Feb. 17. A copy will be sent to ETL to assist in experiment planning.

Reported on an "Overview of the Loch Linnhe 94 trials" at ASAP program review meeting at LLNL, Feb. 8, 1995.

Meeting regarding future field experiments with Mike Yelverton of AUTEC is planned for $2 / 10 / 95$.

Expected milestones for the ensuing period:

A report on the effect of shear on ship internal wave patterns is in progress. Expected completion in 1-2 months.

Other Issues:

None.

Planned expenditures versus actuals:

FY95 Budget Plan: $\quad$ \$2000K

January 95 costs: $\quad \$ 45.7 \mathrm{~K}$

Year-to-date costs: $\quad \$ 413.7 \mathrm{~K}$ 
Organization: LLNL

Program: P.LLN.1070 Data Analysis and Detection Theory

Principal Investigator: James M. Brase

\section{Current Objectives:}

Complete baseline analysis of Loch Linnhe data.

Complete report on MTF for LGA data (1989-94 data sets).

Continue Doppler analysis and detection implications.

Analysis of UCSB data as it comes in.

\section{Recent accomplishments:}

Completed calibration of LL94 data. Priority 1 run ready to distribute

Doppler analysis of P1 94 run completed showing variation of wake visibility in side wind case.

Completed report on nonlinear filtering of radar data.

Milestones for the reporting period:

Initial report on nonlinear filtering completed.

Expected milestones for the ensuing period:

Report on November ship wake meeting in February ' 95.

Parametric study of LGA image quality for 1989-94 database in February '95.

Full analysis reports for LL-94 in March '95.

Report on initial UCSB impulse radar experiments in March 95.

Other Issues:

None.

Planned expenditures versus actuals:

FY95 Budget Plan: $\quad \$ 700 \mathrm{~K}$

January 95 costs: $\quad \$ 89.3 \mathrm{~K}$

Year-to-date costs: $\quad \$ 461.4 \mathrm{~K}$ 
Organization: LLNL

Program: P.LLN.1080 Management

Principal Investigator: Richard E. Twogood

Current Objectives:

Provide ongoing management oversight and support for the Joint UK/US

Radar Program (Twogood) and staff support in Washington for the ASAP program office (Thomson, Hutchins, Chocol), in addition to other consultant and management services (Wells, Manasse, etc.). All administrative support for UK/US program included.

\section{Recent accomplishments:}

Coordination of future meetings and new initiatives was performed.

Continued full-time support of ISSO Ballston office by Thomson, Hutchins, and Chocol.

Milestones for the reporting period:

None

Expected milestones for the ensuing period:

Ongoing support to ISSO office by program office staff. Quarterly project meeting scheduled at LLNL 2/7-8/95

Coordination and briefing for Scientific Advisory Group in February 95.

Other Issues:

None.

Planned expenditures versus actuals:

FY95 Budget Plan: $\quad \$ 1000 \mathrm{~K}$

January 95 costs: $\quad \$ 195.2 \mathrm{~K}$

Year-to-date costs: $\quad \$ 1086.6 \mathrm{~K}$ (includes accruals of overruns from FY94, approximately $\$ 400 \mathrm{~K}$ ) 
Organization: LLNL

Program: P.LLN.1090 E-2C Radar Data Analysis

Principal Investigator: Charles Rino

Inputs to be provided separately to ISSO directly by Vista Research. 
Organization: LLNL

Program: P.LLN.1110 Modeling and Analysis (LLNL)

Principal Investigator: David Chambers

Current Objectives:

Analysis of Loch Linnhe 1994 hydrodynamics data.

Development of turbulent wake model.

Estimate wind-wave relaxation times.

Recent accomplishments:

Continued analysis of Loch Linnhe hydro data. Completed initial comparison of wake model to IAP tank data.

Milestones for the reporting period:

Successfully simulated Stokes wave with and without wind.

Expected milestones for the ensuing period:

Documentation of hydro analysis for Loch Linnhe by March 1995.

Complete first upgrade of turbulent wake model and compare with IAP data.

Simulate wave similar to those produced in UCSB wave tank.

\section{Other Issues:}

None.

Planned expenditures versus actuals:

FY95 Budget Plan:

January 95 costs:

$\$ 330 \mathrm{~K}$

Year-to-date costs:

$\$ 17.7 \mathrm{~K}$

$\$ 65.7 \mathrm{~K}$ 
Organization: LLNL

Program: P.LLN.1150 Modeling and Analysis (Vista)

Inputs to be provided to ISSO directly by Vista Research. 
Organization: LLNL

Program: $\quad$ P.LLN.1170 Current Meter Array

Principal Investigator: David Mantrom

\section{Current Objectives:}

Loch Linnhe 1994 CMA data analysis and documentation.

Upgrades to power system, structure, and data acquisition for future tests.

\section{Recent accomplishments:}

We have continued our analysis of LL94 CMA data. We received revised GPS position data for the CMA and the target ships. (About $1 / 2$ of the original ship track data and 1/4 of the CMA position data was usable). We are making a direct effort to understand why ship-generated IW's were seen by the CMA in some records and not in others. We are looking at operating and environmental effects on IW generation and ambient noise levels. Results from applying one noise rejection algorithm to the ship wake data show little benefit. We are in the process of formulating a different approach.

We have put aside upgrades to the CMA pending resolution of uncertainties involving future field experiments.

\section{Milestones for the reporting period:}

None.

Expected milestones for the ensuing period:

Completion of data analysis with noise rejection algorithm \#2.

List of upgrade requirements for 1995 CMA deployment(s).

Other Issues:

None.

Planned expenditures versus actuals:

FY95 Budget Plan: $\$ 300 \mathrm{~K}$

January 95 costs: $\quad \$ 17.5 \mathrm{~K}$

Year-to-date costs: $\quad \$ 17.5 \mathrm{~K}$ 
Organization: LLNL

\section{Program: P.LLN.1410 UCSB Wave Tank}

Principal Investigator: Harry Robey

\section{Current Objectives:}

Continue hydro measurements program at UCSB.

Install radars in tank: initially UCSB's C-band and LLNL's existing wideband; later TRW's $\mathbf{x}$-band. Conduct radar LGA experiments with simultaneous optical and hydro systems. Analyze and report on wave tank results.

\section{Recent accomplishments:}

Based on the planning meeting held in December 94 at UCSB and on subsequent discussions, an experiment plan and schedule has been prepared adn will be summarized at the quarterly UK/US meeting at LLNL on 2/78/95. The plan covers scheduled experiments for the UCSB, TRW, and LLNL radars, as well as related diagnostics.

Preliminary results from analysis of both the UCSB and LLNL radar tests already conducted at UCSB are extremely encouraging. LGA test data have been successfully obtained, and analysis of $\mathrm{HH} / \mathrm{VV}$ ratios, doppler effects, and wave group behavior docmented. Details will be presented at the LLNL quarterly meeting in February 95.

\section{Milestones for the reporting period:}

Draft experiment pian and schedule compared. Preliminary analysis of UCSB and LLNL radar data.

Expected milestones for the ensuing period:

Installation of LLNL wideband system (on more or less permanent basis) 2/95. Installation of TRW radar circa 3/95.

\section{Other Issues:}

None.

Planned expenditures versus actuals:

FY95 Budget Plan: $\quad \$ 800 \mathrm{~K}$

January 95 costs: $\quad \$ 28.7 \mathrm{~K}$

Year-to-date costs: $\quad \$ 171.6 \mathrm{~K}$ 
Organization: LLNL

Program: P.LLN.1420 Stratified Flow Facility

Principal Investigator: Harry Robey

\section{Current Objectives:}

Re-start experiments on internal wave generation by a turbulent wake in enlarged test section.

Recent accomplishments:

A flow visualization study of the wake behind slender bodies has been completed. Slender bodies of aspect ratio from 1:1 to 10:1 were used.

Emphasis was on determining the size and convective velocity of the largescale turbulent structures which are believed to be responsible for internal

wave generation from the wake. A report is in preparation.

Further action on upgrading the facility is on hold pending funding.

Milestones for the reporting period:

None.

Expected milestones for the ensuing period:

Further action is on hold pending funding.

\section{Other Issues:}

None.

Planned expenditures versus actuals:

FY95 Budget Plan: $\quad \$ 200 \mathrm{~K}$

January 95 costs: $\quad \$ 39.7 \mathrm{~K}$

Year-to-date costs: $\quad \$ 81.7 \mathrm{~K}$ 
Organization: LLNL

\author{
Program: P.LLN.1430 Institute of Applied Physics, Russia \\ Principal Investigator: Harry Robey
}

\title{
Current Objectives:
}

Conduct wave tank studies in the thermally stratified tank at IAP, Russia. Current emphasis is on a continuation of experiments on internal wave generation by a towed body and its turbulent wake. Also, previous results will be extended to include the effects of shear.

\section{Recent accomplishments:}

Work is underway on phase one of the experiments. This first phase will repeat the experiments using a towed sphere in a thermocline and will address the statistical repeatability of the results previously obtained and documented in Report 3 (Study of Internal Waves Generated by a Moving Body, IAP, 1994).

The results obtained in previous IAP experiments have been analyzed using a kinematic model based on oscillating sources. This model seems to capture several of the unexplained features of the experiments regarding internal waves generated by the wake. This analysis should lead to a much improved modeling capability of such wave generation.

Milestones for the reporting period:

Reported on kinematic analysis of IAP experimental data at ASAP program review meeting at LLNL, Feb. 8, 1995.

Expected milestones for the ensuing period:

Report 1 covering the first phase of the work will be delivered in three months from placement of the contract.

\section{Other Issues:}

None.

Planned expenditures versus actuals:

FY95 Budget Plan:

January 95 costs:

Year-to-date costs:
$\$ 350 \mathrm{~K}$

$\$ 0 \mathrm{~K}$

\$0K (contract liened however) 
Organization: LLNL

Program: P.LLN.1210 IR Sensor Systems

Principal Investigator: Jerry Belyea

Inputs to be provided to ISSO directly by ERIM. 


\section{Budget Status}

Budget breakdown by individual ISSO work assignment are described in the above individual work unit assignments. Overall LLNL funding status is as follows (includes all LLNL costs, including all work units in this report).

\begin{tabular}{lr} 
January 95 costs: & $\$ 1035.8 \mathrm{~K}$ \\
Year-to-date costs: & $\$ 3932.3 \mathrm{~K}$ \\
Ledger liens: & $\$ 2334.0 \mathrm{~K}$ \\
Pre-liens: & $\$ 575.1 \mathrm{~K}$ \\
Non-ledger liens: & $\$ 400.0 \mathrm{~K}$ (est.) (unaccrued costs on liens and \\
& \multicolumn{2}{c}{$\begin{array}{c}\text { preliens plus at-risk funding by } \\
\text { contractors) }\end{array}$} \\
Funds remaining: & $-\$ 2436.4 \mathrm{~K} \quad$ (overrun as of 2/1/95)
\end{tabular}

Discussion of funding: ISSO has sent a $\$ 7.0 \mathrm{M}$ MIPR to address the above overrun. Steps that were underway to stop UK/US program activities and stop work at contractors have been delayed due to action taken by the Director of ISSO to get funding released to LLNL. An additional $\$ 2.6 \mathrm{M}$ (estimated) is expected to be sent by ISSO in February, bringing all tasks covered by this report to full FY95 (includes IR work at ERIM only through April 95, however). 